\title{
Passion Fruit Problems in the Home Landscape ${ }^{1}$
}

\author{
Amir Rezazadeh, Mark Bailey, and Ali Sarkhosh²
}

Passion fruit (Passiflora edulis) belongs to the genus Passiflora, a large genus in the family Passifloraceae consisting of approximately 530 species, many of which are cultivated for edible fruit, pharmaceutical properties, and ornamental characteristics (Vanderplank 1996). Passiflora vines can be propagated sexually through seeds or asexually by cutting, air-layering, and grafting. Popular cultivars include purple passion fruit (Passiflora edulis) and yellow passion fruit (Passiflora edulis flavicarpa), with the purple passion fruit being the more common type. The fruit can be consumed fresh or processed for juice, flavoring, or value-added products like jams and jellies. The fruit is round or eggshaped and $2 \frac{1}{2}$ to 3 inches long $(6.3$ to $7.6 \mathrm{~cm}$ ). The yellow passion fruit is very similar to the purple type except for its skin color.

In Florida, purple and yellow passion fruit have been widely cultivated by homeowners for years, and south Florida's subtropical climate allows for growing passion fruit yearround. Many factors affect longevity and productivity of passion fruit vine, including environmental stresses, pests, and disease. This document is designed to help Master Gardeners and homeowners by answering commonly asked questions about passion fruit production problems.

\section{Propagation}

\section{Why are my seeds not germinating?}

Passion fruit seeds are often slow to germinate and have low germination rates due to seed dormancy factors. Fruit should be completely ripe before seeds are extracted. Seeds will germinate in two to three weeks if planted soon after removal from the fruit. Seeds show a slower and lower germination rate when they are stored for long periods. Pre-germination treatments such as soaking in water, scarification (abrading) with sandpaper, and fermentation for a few days can improve germination rate.

\section{Flowering, Fruit Set, and Fruit Quality}

\section{Why is my passion fruit vine not flowering?}

Young vines do not produce flowers until they have reached maturity, which can take up to a year. Once a vine has reached maturity and has adequate access to sunlight, nutrients, and water, flowers should be produced on the new growth (Figure 1). Flowers may not always emerge on new growth, especially if the passion fruit has been excessively fertilized. Excessive application of nitrogen fertilizer in particular can contribute to excessive vegetative growth rather than flowering. To encourage flowering, reduce fertilizer rates once the vine has reached maturity.

\section{Why is my passion fruit vine flowering but not setting fruit?}

Passion fruit flowers have both male and female parts and can be self-compatible (self-pollinating) or selfincompatible (not self-pollinating), depending on variety. The yellow passion fruit is largely self-incompatible; therefore, cross-pollination is necessary for seed and fruit set (McGregor 1976). The purple passion fruit varieties and their hybrids are self-compatible, and no cross-pollination

1. This document is HS1397, one of a series of the Horticultural Sciences Department, UF/IFAS Extension. Original publication date November 2020. Visit the EDIS website at https://edis.ifas.ufl.edu for the currently supported version of this publication.

2. Amir Rezazadeh, Extension agent II, UF/IFAS Extension St. Lucie County; Mark Bailey, Extension agent I, UF/IFAS Extension Marion County; and Ali Sarkhosh, assistant professor, Horticultural Sciences Department; UF/IFAS Extension, Gainesville, FL 32611.

The Institute of Food and Agricultural Sciences (IFAS) is an Equal Opportunity Institution authorized to provide research, educational information and other services

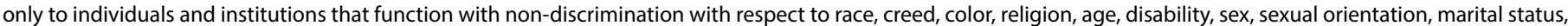

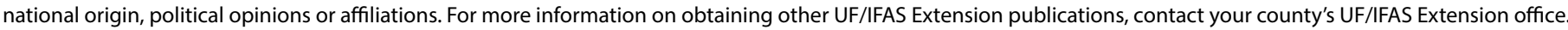
U.S. Department of Agriculture, UF/IFAS Extension Service, University of Florida, IFAS, Florida A \& M University Cooperative Extension Program, and Boards of County Commissioners Cooperating. Nick T. Place, dean for UF/IFAS Extension. 
is required (McCarthy and Dick 2007). However, some varieties and hybrids have partial self-incompatibility and should be planted with other varieties.

Due to flower morphology (Figure 2), the anthers are below the stigmas, and they need external pollination by insects or by hand. Wind pollination is ineffective because pollen grains are heavy and sticky (Souza et al. 2004). The primary pollinators of passion fruit are honey bees and carpenter bees (Xylocopa spp.). Hand-pollination is needed when the population of pollinating insects is insufficient. This can be done by using clean cotton gloves or a paintbrush to collect pollen from the anther and transfer the pollen from flower to flower by touching the stigma. Poor pollination also can happen due to too much rain, high humidity, and too high or too low temperature.

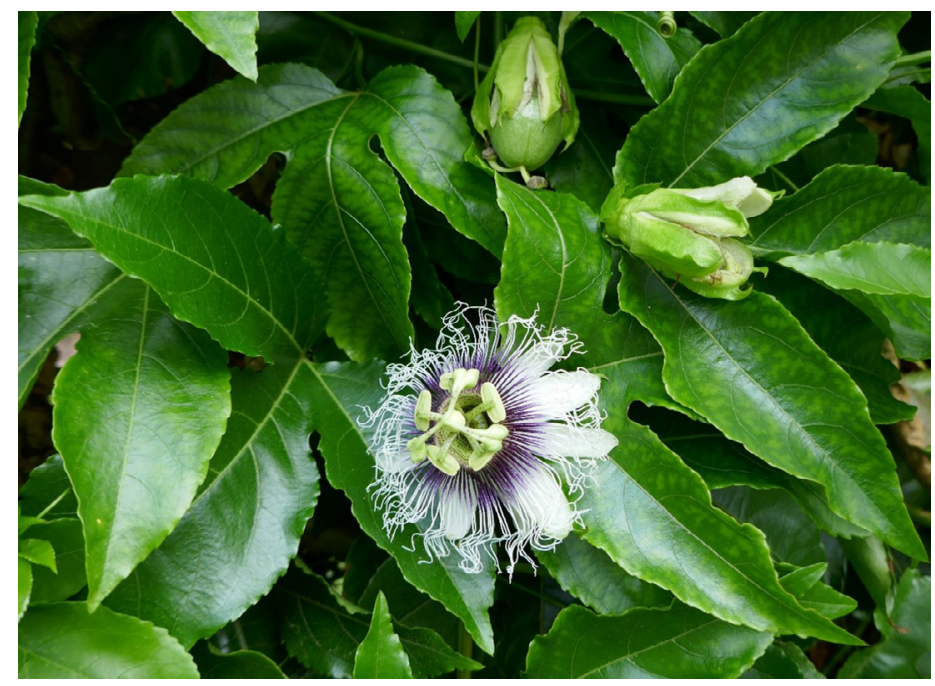

Figure 1. Passion fruit flower and developing fruit.

Credits: Mark Bailey, UF/IFAS

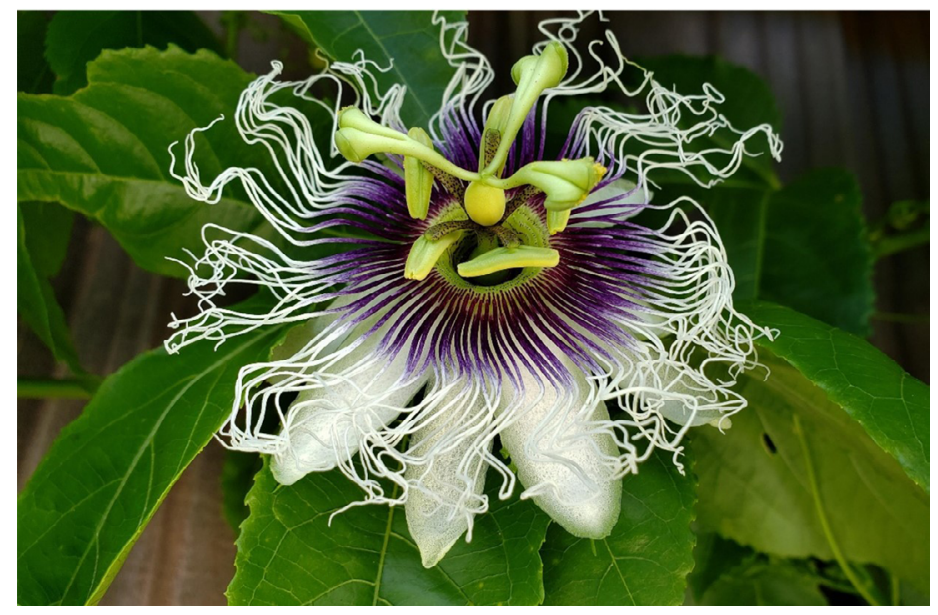

Figure 2. Flower morphology of passion fruit.

Credits: Amir Rezazadeh, UF/IFAS

\section{Why do passion fruit vines produce fruit with soft seeds but no juice?}

Lack of arils (the pulpy tissue surrounding the seed) may be attributed to water or nutrient deficiency. Empty fruit on a passion fruit vine can be a result of excess fertilizer, particularly if large amounts of nitrogen are used. Other reasons may be fruit fly damage, stink bug damage, poor pollination, or boron deficiency (Figure 3).

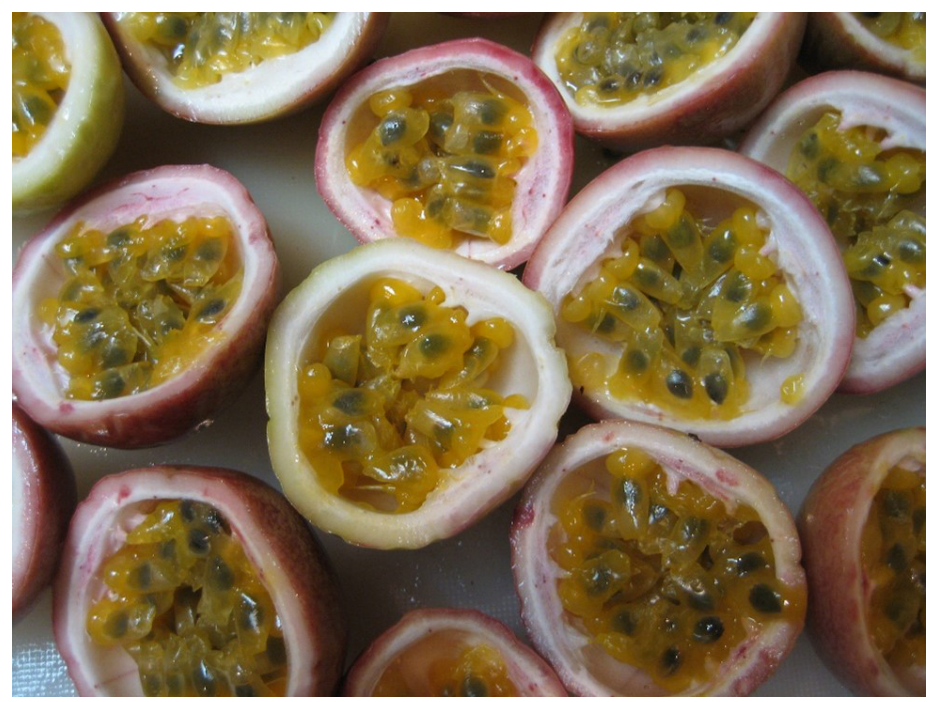

Figure 3. Passion fruit halves with typical aril fill. Credits: Mark Bailey, UF/IFAS

\section{Why does passion fruit drop prematurely?}

Premature fruit drop may be due to one of the following reasons. Irregular watering may cause fruit drop because passion fruit have a high water requirement when the fruit are approaching maturity. Water stress results in fruit shriveling and drop. Consistent irrigation and increasing organic matter in the soil can greatly improve water availability for the vine. Other possible reasons include nutrient deficiency, fungal disease, and fruit fly and mite damage.

\section{Why are my fruit misshaped or malformed?}

There are several causes of bumpy or malformed fruit, such as passion fruit woodiness virus, boron deficiency, and insect damage, particularly fruit fly.

\section{Disease}

\section{Why are the passion fruit leaves distorted?}

Distorted leaves are one of the symptoms of woodiness virus (Figure 4). The common symptoms of this disease include fruit with a thick rind and small pulp cavity. Leaves display a dark-green pattern with light-yellow spots. The leaves are often distorted and crinkled. Other common symptoms are leaf mottling, ring spot on the younger leaves, chlorotic spots on the leaves, and faded fruit. Aphids can transmit this virus by feeding on an infected plant and 
then feeding on an uninfected plant. The virus can also be transmitted through pruning tools and grafting. The virus is not transmitted through seeds. Common cultural practices to manage the disease are selecting virus-free planting materials, eliminating mechanical transmission during trimming, and regularly inspecting and roguing diseased plants. Although there are insecticides to control aphids, prevention is more effective because the virus spreads quickly.

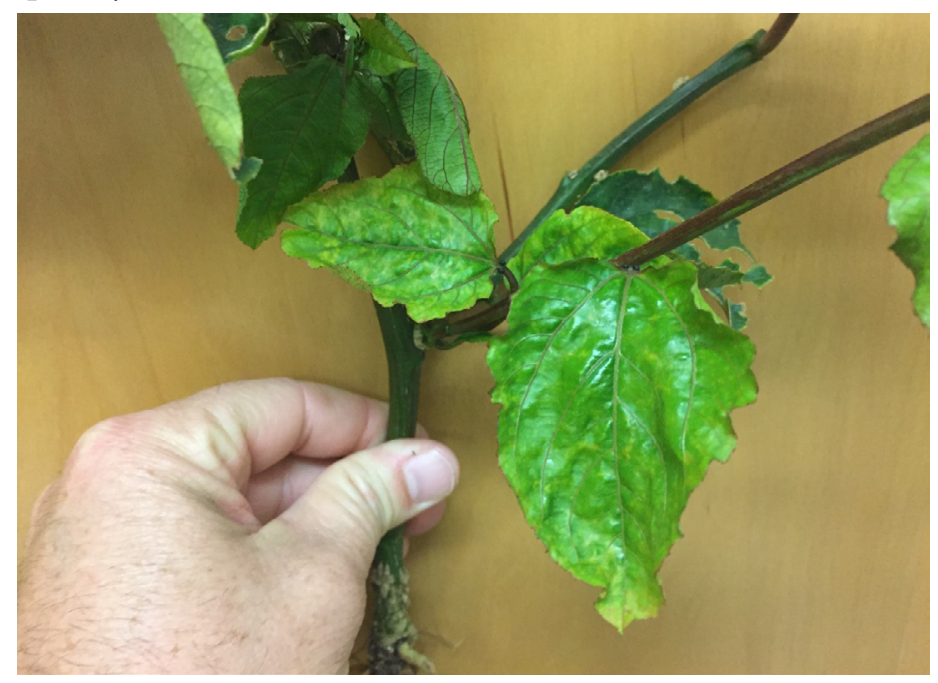

Figure 4. Leaves of passion fruit infected with passion fruit woodiness virus are distorted.

Credits: Jeff Wasielewski, UF/IFAS

\section{Why do gray spots appear on fruits?}

Brown spot of passion fruit is caused by the fungi Alternaria passiflora and A. alternata. The symptoms can be seen on leaves, stems, and fruit. On fruit, the symptoms appear as tiny gray spots, then light brown, and finally dark brown with wrinkled centers, affecting the pulp and decreasing commercial value of fruit. The symptoms on the leaves include reddish-brown spots, becoming light brown later. Spots enlarge to one inch in diameter under high humidity. Leaves drop after developing a few spots. On stems, darkbrown lesions are more elongated and cause girdling and eventually death of the terminal part of the stem. Wind, water, and rain can spread the fungal spores produced on the fruit, leaves, and stems. The disease can be more intense under high humidity or high temperature and in the rainy season. Brown spot can be managed by spacing and pruning plants so that air can circulate (Figure 5) and increase ventilation and light conditions. Weed control, improved sanitation, and preventive applications of fungicide can also help to manage the disease.

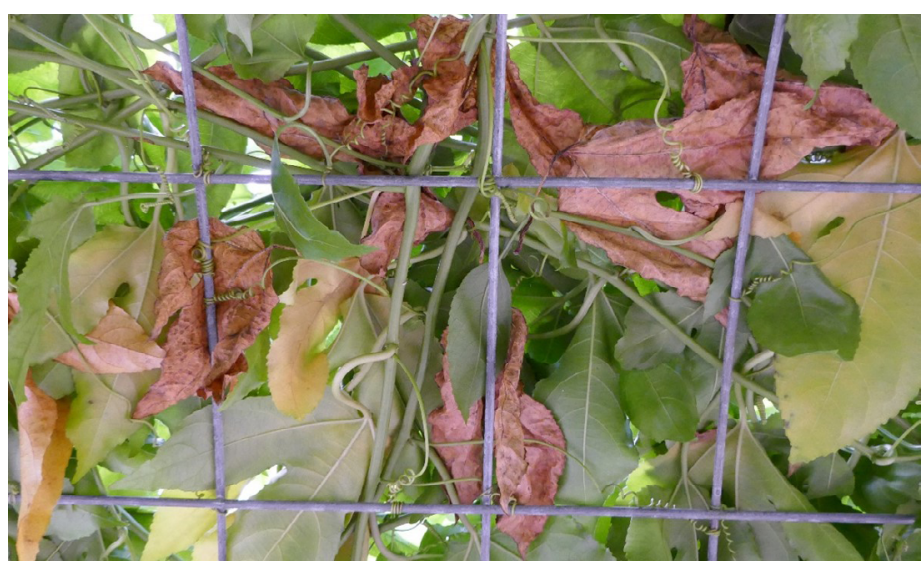

Figure 5. Dead leaves under new leaves hindering airflow and facilitating disease.

Credits: Mark Bailey, UF/IFAS

\section{Why is my passion fruit vine wilting?}

One of the most harmful diseases of passion fruit is fusarium wilt, caused by the fungus Fusarium oxysporum (Figure 6). On young plants, the symptoms include palegreen leaves, mild dieback, leaf drop on lower leaves, and general plant wilting. Yellowing of young leaves appears in adult plants, followed by wilting and death. The disease affects the xylem, causing impermeability of vascular walls and preventing the movement of water to other plant parts. Thus, the vascular tissues become brown at the root, collar, stem, and twig areas. The pathogen can spread by soil movement (machines, implements, shoes, etc.) and by water runoff or irrigation. The disease severity is greater in high relative humidity and temperature.

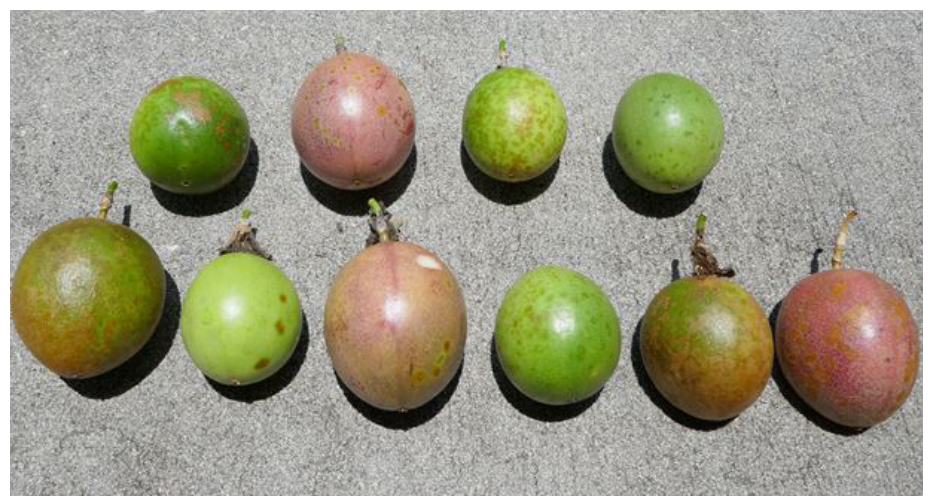

Figure 6. Fusarium affecting fruit at various stages of maturity. Credits: Mark Bailey, UF/IFAS

Avoid planting in previously affected areas. Plant diseasefree seedlings, and avoid injuring plants' stems and roots in order to prevent the spread of disease. Another control method is using resistant rootstocks or resistant hybrids between purple and yellow passion fruit (Nelson et al. 1983).

Another fungal disease causing sudden wilting in passion fruit is collar rot, caused by Haematonectria haematococca and Fusarium solani. The symptoms appear as pale-green 
leaves and mild dieback of the plants. The necrotic girdling of the plant collar leads to wilting, defoliation, and finally, death. Plants may be infected one to two years after planting. Avoid planting in the same location to prevent infection, because the fungus remains viable in the soil for up to four years. The fungus can spread by soil movement and favors high temperature and humidity. Poor drainage, excessive soil moisture, and injuries to the plant collar and roots increase the incidence of this disease. The use of resistant rootstock to prevent infection is more effective than using fungicide while conditions are favorable for disease (Nelson et al. 1983).

\section{The leaves are pale green, wilting, and falling off the vine-why?}

Root and crown rot is a fungal disease caused by Phytophthora cinnamomic and $P$. nicotianae. The typical symptoms include chlorosis, wilting, defoliation, and death. Other common symptoms include scorched leaves and aborted flowers. Soil with low drainage, long periods of rainfall, and high temperature increase the incidence of the disease. To prevent the disease, use disease-free plant material. Application of a registered fungicide on the plant collar may be effective if applied in the rainy season (Grech and Rijkenberg 1991).

\section{Why do sunken gray lesions appear on fruit surfaces?} Colletotrichum gloeosporioides is the fungus that causes anthracnose in passion fruit. Common symptoms include defoliation; wilt and dieback; fruit rot; dark-brown spots on the leaves, branches, and fruits; immature fruit abortion; and eventual wilting and death of the plant. The fungus can spread by water droplets, infected seeds, seedlings, and cuttings. Moisture and high temperatures increase incidence of the disease. Best management strategies to control the disease include using disease-free seedlings, pruning to eliminate infected shoots, and increasing air circulation and light conditions. Preventive fungicide applications in favorable conditions are recommended. Joy and Sherin (2012) found that decreasing thatching of the leaves will greatly increase airflow around the plant.

\section{What are the small, dark, corklike lesions on fruits?}

One of the most common fungal diseases of passion fruit is scab, a disease caused by the fungus Cladosporium oxysporum. Small, translucent round spots appear on the leaves and over time become necrotic with greenish-gray centers. Advanced symptoms include leaf deformity, leaf drop, and flower buds. There can be similar spots on twigs and twig tips, which later turn into cankers with sunken greenishgray lesions. On small fruit, symptoms appear as sunken, small, dark, circular spots. As fruit enlarge, lesions grow and become corklike and brownish, resulting in deformed and stunted fruit. Additionally, twig dieback, flowering delay, and reduction of fruit quality may occur.

The pathogen primarily spreads by infected seedlings, wind, and water droplets. Young, actively growing tissue is most susceptible; thus, high humidity increases susceptibility to the disease. To control scab, avoid high density of seedlings and excessive irrigation. Fungicide application can help control this disease. To prevent the pathogens from spreading, cultural practices include increased air flow and tool sanitation.

\section{What is the cause of dark, brownish-green, irregular lesions with hard crust on fruits?}

Bacterial spot is a bacterial disease caused by Xanthomonas axonopodis. First, small, dark green spots encircled by a chlorotic halo appear on the leaves. In humid conditions, the lesions become bigger and brown, leading to entire leaves wilting and dropping. The pathogen then spreads through leaf veins and affects the vascular system, resulting in darkening of the vascular system. Fruit production declines, and eventually the plant may die. Fruit display dark brownish-green circular or irregular lesions. The lesions penetrate the pulp and result in unmarketable fruit or fruit drop.

The pathogen is transmitted through wind, rain, irrigation, and infected seedlings. High temperature along with high relative humidity will increase the disease incidence and severity. The most effective control method is through use of disease-free stock, because chemical control is ineffective. Avoid planting in previously infected areas. Other cultural practices include using wind breaks, avoiding overirrigation, removing infected plant parts, and sanitizing pruning tools.

\section{Insects}

\section{What are those small holes in the leaves?}

The pest Agraulis vanillae L., the Gulf fritillary caterpillar (Figure 7), feeds exclusively on passion fruit foliage. By feeding on leaves, they severely damage the plant and indirectly reduce fruit yield. Although several parasitoids have been identified for this pest, none of them are consistently effective on a large scale.

To control the pest, scout plants regularly. Hand removal and destruction of eggs and caterpillars is an effective practice. On a larger scale, insecticide spray is more effective to control defoliator caterpillars. To improve crop yield, it is important to spray insecticides that are effective on caterpillars but safe for other pollinator insects. 


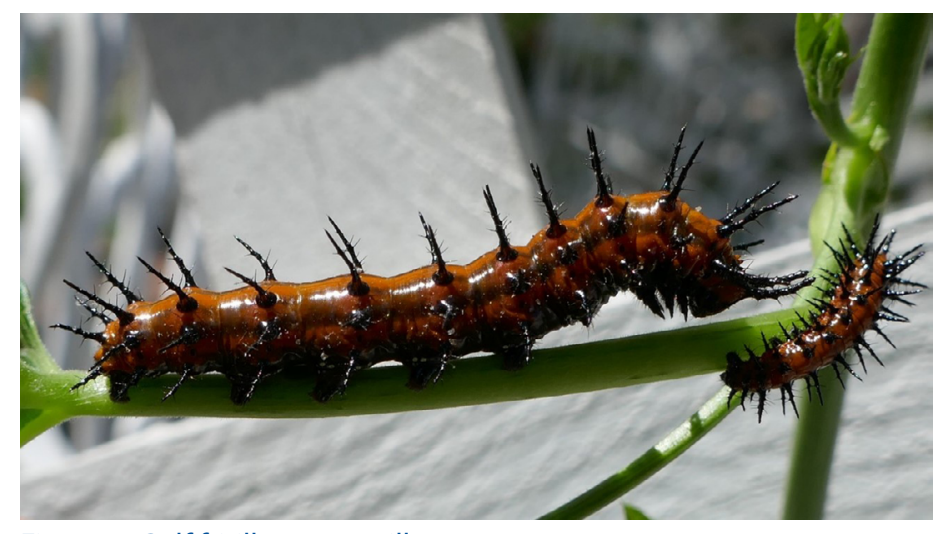

Figure 7. Gulf fritillary caterpillar.

Credits: Mark Bailey, UF/IFAS

\section{Why do small holes and woody lumps appear on} fruits?

Three species of fruit fly, Anastrepha schiner (Tephritidae), Lonchaea fallen (Lonchaeidae), and A. consobrina, are potential pests on passion fruit vines. The flies feed on the fruit, causing premature fruit drop. If the flies puncture premature fruit with a tender rind, a woody area develops around the puncture, causing cosmetic damage. For maturing fruit, the damage by a puncture or egg-laying likely will cause fruit to shrivel or drop. Cosmetically damaged fruit lose fresh marketability, but they can still be processed for juice.

To control fruit flies, remove overripe fruit on which they breed. Plant passion vines far away from other potential fly host plants.

\section{What is the reason for yellowing, shriveling, and falling leaves?}

Mites are one of the most common pests that infest passion fruit plants. As mites feed on the undersides of leaves, yellow discoloration on the upper side of the leaf appears as the initial symptom. As the damage advances, these spots turn into brownish, dry patches of necrotic plant tissue. Extreme mite infestations are lethal. One of the distinctive signs of a dense population of mites is the silken webs they produce. Mites also attack flower buds and, consequently, decrease fruit set and accelerate premature fruit drop.

Warm temperature and low humidity are two favorable conditions for mites. To control mites, periodic inspection of vines and other adjacent plants is essential to verify the first symptom of mite attack. Application of a selective miticide as soon as first symptoms appear is effective to control mites.
Why are leaves curling and displaying malformation?

Aphids are not recognized as a primary pest on passion fruit and seldom cause serious damage. However, controlling aphids is essential because they are a major vector of passion fruit woodiness virus. Aphids damage plants by sucking plant sap, causing leaf curling, wrinkling, and malformation. Proper use of an appropriate insecticide on passion fruit vines and the host plants near vines is the most effective control method.

\section{References}

Grech, N. M., and F. H. G. Rijkenberg. 1991. "Laboratory and Field Evaluation of the Performance of Passiflora caerulia as a Rootstock Tolerant to Certain Fungal Pathogens." Journal of Horticultural Science 66 (6): 725-729. https://doi. org/10.1080/00221589.1991.11516204

Joy, P. P., and C. G. Sherin. 2012. "Diseases of Passion Fruit (Passiflora edulis): Pathogen, Symptoms, Infection, Spread and Management." http://www.kau.in/sites/default/files/ documents/diseases_of_passion_fruit.pdf

McCarthy, A., and J. Dick. 2007. "Passion Fruit Culture." Farmnote. Department of Agriculture, Western Australia.

McGregor, S. E. 1976. Insect Pollination of Cultivated Crop Plants. Tucson: USDA.

Nelson, P. E., T. A. Toussoun, and W. O. Marasas. 1983. Fusarium Species: An Illustrated Guide for Identification. University Park: Pennsylvania State University Press.

Souza, M. M., T. S. Pereira, A. P. Viana, M. G. Pereira, A. T. Amaral, and H. C. Madureira. 2004. "Flower Receptivity and Fruit Characteristics Associated to Time of Pollination in the Yellow Passion Fruit Passiflora edulis Sims f. flavicarpa Degener (Passifloraceae)." Scientia Horticulturae 101 (4): 373-385. https://doi.org/10.1016/j.scienta.2003.11.020

Vanderplank, J. 1996. Passion Flowers and Passion Fruit. 2nd Ed. Cambridge, MA: MIT Press. 